\title{
Experimental neosporosis in bulls: Parasite detection in semen and blood and specific antibody and interferon-gamma responses
}

\author{
E. Serrano-Martínez ${ }^{\text {a }}$, I. Ferre ${ }^{\text {a }}$, A. Martínez ${ }^{\text {b }}$, K. Osoro ${ }^{\text {b }}$, A. Mateos-Sanz ${ }^{\text {a }}$,

 \\ ${ }^{a}$ Grupo SALUVET. Departamento de Sanidad Animal, Facultad de Veterinaria, Universidad Complutense de Madrid (UCM), \\ Ciudad Universitaria s/n, E-28040 Madrid, Spain \\ ${ }^{\mathrm{b}}$ Área de Sistemas de Producción Animal, Servicio Regional de Investigación y Desarrollo Agroalimentario (SERIDA), \\ Consejería de Medio Rural y Pesca, Asturias, E-33300 Villaviciosa, Spain \\ ${ }^{\mathrm{c}}$ Departamento de Sanidad Animal, Instituto Vasco de Investigación y Desarrollo Agrario (NEIKER), Berreaga 1, \\ E-48160 Derio, Bizkaia, Spain \\ dÁrea de Selección y Reproducción Animal, Servicio Regional de Investigación y Desarrollo Agroalimentario (SERIDA), \\ Consejería de Medio Rural y Pesca, Asturias, E-33202 Gijón, Spain
}

Received 22 November 2006; received in revised form 22 December 2006; accepted 16 January 2007

\begin{abstract}
Aim: To investigate the presence of Neospora caninum in semen and blood, and the development of specific antibody and interferon-gamma (IFN- $\gamma$ ) responses in experimentally infected bulls.

Methods: Eight bulls were intravenously infected with $10^{8}$ live $N$. caninum tachyzoites of NC-1 isolate. The presence of $N$. caninum in semen and blood was assessed using a nested-PCR procedure. PCR-positive semen samples were bioassayed using a BALB/c nu/nu mouse model. Specific anti- $N$. caninum antibody and IFN- $\gamma$ responses were also examined. In parallel, eight seronegative bulls were studied as non-infected controls. All bulls were monitored for 26 weeks.

Results: All eight experimentally infected bulls showed N. caninum DNA in their semen and/or blood samples at some time during the course of the study. Parasite load in semen ranged from 0.1 to 14.5 parasites $/ \mathrm{ml}$ (mean 6.0). N. caninum could not be detected in $\mathrm{BALB} / \mathrm{c} n u / n u$ mice inoculated with PCR-positive semen samples. A significant increase in mean serum specific IgM antibody response to $N$. caninum was detected between 10 and 28 days post-infection (p.i.). Serum specific IgG, IgG1, and IgG2 antibody levels in experimentally infected bulls were significantly different after 21,10 , and 14 days p.i. as compared to controls, respectively. Specific anti- $N$. caninum $\operatorname{IgG}$ were detected in seminal plasma from infected bulls and values obtained were different from controls after 25 days p.i. Mean specific IFN- $\gamma$ responses in experimentally infected bulls were significantly higher than controls 3 days p.i.

Conclusions: This is the first study to report the presence of $N$. caninum DNA in the semen and blood of experimentally infected bulls. Our observations indicate an intermittent presence of $N$. caninum in low numbers in semen and associated with chronic stage of the infection. This study is also the first to report the detection of anti- $N$. caninum $\operatorname{IgG}$ in seminal plasma of experimentally infected bulls.
\end{abstract}

(C) 2007 Elsevier Inc. All rights reserved.

Keywords: Neospora caninum; Bull; Experimental infection; Semen; Immune response

\footnotetext{
* Corresponding author. Tel.: +34 91 3944069; fax: +34 913943908.

E-mail address: luis.ortega@ vet.ucm.es (L.M. Ortega-Mora).
} 


\section{Introduction}

Neospora caninum is a heteroxenous cyst-forming apicomplexan and is a common cause of foetopathy and abortion in cattle worldwide [1]. Since $N$. caninum DNA was reported in fresh and frozen semen from naturally infected bulls $[2,3]$, the possibility of venereal transmission has been suggested to be a cause of bovine neosporosis. A follow-up study carried out in eight naturally infected bulls located in a Spanish AI centre showed the intermittent presence of Neospora DNA in the semen of six animals [4]. However, the parasite load found in semen samples was notably low (mean of 3 parasites $/ \mathrm{ml}$ of semen ranging between 1 and 10 parasites $/ \mathrm{ml}$ of semen) and $N$. caninum could not be detected in BALB/c $n u / n u$ mice inoculated with PCR-positive semen samples. Recently, Staubli et al. [5] were unable to find Neospora DNA in 20 seropositive bulls used for AI in Switzerland. On the other hand, intrauterine inoculation of $10^{7} \mathrm{~N}$. caninum $\mathrm{NC}-1$ isolate-tachyzoites in heifers was reported [6]. In that study, nine inoculated heifers reacted with seroconversion and a specific IFN- $\gamma$ response. Moreover, $N$. caninum DNA was demonstrated in the blood of all nine heifers and in the brain, liver and uterine horn in a subset of the animals. Recently, intrauterine $N$. caninum inoculation of heifers using contaminated semen with different numbers of tachyzoites was studied [7]. This report provides evidence that intrauterine infection via contaminated semen using $5 \times 10^{4}$ and $5 \times 10^{5}$ tachyzoites caused persistent serum-specific antibody responses in some heifers. On the basis of serological data, a dose-response effect was also observed.

In order to investigate the pattern of the presence of this protozoan in semen and blood during acute and chronic neosporosis, we describe in this paper a followup study in bulls experimentally infected with $N$. caninum. In addition, specific antibody and IFN- $\gamma$ responses were studied and positive semen samples were bioassayed in a BALB/c nu/nu mouse model.

\section{Material and methods}

\subsection{Bulls and housing}

Sixteen bulls raised for reproductive purposes in a collaborating AI centre (Asociación de Criadores de Ganado Vacuno Selecto de la Raza Asturiana de los Valles, ASEAVA) and trained for semen collection were selected for this study. The breed was Asturiana de los Valles, ranging in age from 3.4 to 6.5 (mean 4.3) years old and weighing from 764 to 1058 (median 870) $\mathrm{Kg}$. During the course of the experiment, bulls were located in individual pens under strict nutritional, hygiene and management control in SERIDA facilities (Servicio Regional de Investigación y Desarrollo Agroalimentario, Asturias, Spain) to minimize the possibility of $N$. caninum horizontal transmission. Prior to the start of the experiment, blood samples were taken from all 16 bulls twice and tested by ELISA (CIVTEST, Hipra Laboratories S.A., Girona, Spain) for evidence of N. caninum exposure. All samples tested seronegative. All bulls produced high quality semen with normal sperm morphology and good fertility rates (data not shown).

\subsection{Experimental design, observations and investigations}

Bulls were randomly allocated into two groups of eight animals. Eight bulls were experimentally infected intravenously with $10^{8}$ live $N$. caninum tachyzoites of $\mathrm{NC}-1$ isolate. In parallel, the other eight bulls were maintained as non-infected controls. The presence of $N$. caninum DNA in semen and blood was investigated, and serological (IgG, IgG1, IgG2, and IgM) and IFN- $\gamma$ responses were also tested. In addition, the presence and levels of specific $\operatorname{IgG}$ and $\operatorname{IgA}$ in seminal plasma was investigated. Experimental animals were monitored for 26 weeks. Bulls were observed twice daily throughout the experimental period. Rectal temperatures of all animals were measured and recorded two weeks prior to inoculation and then daily for two weeks thereafter. In addition, semen samples from experimentally infected bulls were bioassayed in a BALB/c nu/nu mouse model.

\subsection{Parasite inoculum}

Tachyzoites used for experimental infections were obtained from monkey kidney cell (MARC-145) monolayer cultures of the $N$. caninum $\mathrm{NC}-1$ isolate. Briefly, cells were maintained in Dulbecco's modified Eagle medium supplemented with $10 \%$ foetal bovine serum, $\quad 15 \mathrm{mM} \quad N$-2-hydroxyethylpiperazine- $N^{\prime}-2$ ethane-sulfonic acid ( $\mathrm{pH} 7.2), 2 \mathrm{mM}$ glutamine, $100 \mathrm{U} / \mathrm{ml}$ penicillin, $100 \mu \mathrm{g} / \mathrm{ml}$ streptomycin, and $250 \mathrm{ng} / \mathrm{ml}$ fungizone, and incubated at $37^{\circ} \mathrm{C}, 5 \%$ $\mathrm{CO}_{2}$. Cells were passaged twice weekly. Tachyzoites were maintained by serial passage on MARC-145 monolayers at a 1:1 host-parasite ratio, and were harvested from monolayers after four days of culture by scraping the parasite-infected cell monolayer using a sterile cell scraper. Cells were washed three times in sterile 0.3 M phosphate-buffered saline (PBS, pH 7.4) 
and separated from host cell debris by passing the mixture through a 25-gauge needle after passage through a $5 \mu \mathrm{m}$ polycarbonate filter. Tachyzoites were counted in a haemocytometer and resuspended in PBS. Parasite viability was determined by trypan blue exclusion, followed by counting 3 aliquots in a Neubauer chamber. Tachyzoite doses $\left(10^{8}\right)$ were diluted in $2 \mathrm{ml}$ of PBS and packed in $5 \mathrm{ml}$ sterile syringes, which were transported in an insulated box $\left(37^{\circ} \mathrm{C}\right)$ to the animal house for use. Parasites were administered to bulls within $30 \mathrm{~min}$ of harvest from tissue culture.

\subsection{Sample collection and preparation}

Semen samples were collected from bulls with the help of an artificial vagina. Fresh semen samples were obtained on the same day for all animals, once weekly and fortnightly from experimentally infected and control bulls, respectively. After collection, semen samples were stored at $4{ }^{\circ} \mathrm{C}$ for PCR, and processed within $20 \mathrm{~h}$ of collection. For PCR, each semen sample $(400 \mu \mathrm{l})$ was separated into seminal fluid and cellular (non-sperm and sperm cells) fractions by centrifugation $(12,000 \times g$, $3 \mathrm{~min}$ ). Total DNA was extracted from seminal fluid and non-sperm cells of semen using a Genomic-Prep cell and tissue DNA isolation kit (Amersham Biosciences Ltd., UK) as described [2]. A negative control $(400 \mu \mathrm{l})$ of sterile distilled water (Sigma, USA) and a positive control $(400 \mu \mathrm{l})$ consisting of DNA extracted from $400 \mu \mathrm{l}$ semen sample spiked with $10^{2} \mathrm{~N}$. caninum $\mathrm{NC}-1$ isolate tachyzoites were processed as described above to detect possible contamination incurred during the DNA extraction process. Aliquots $(300 \mu \mathrm{l})$ of seminal plasma were stored at $-20{ }^{\circ} \mathrm{C}$ for specific antibody determinations. For bioassay in athymic mice, $400 \mu l$ of semen from each experimentally infected bull was centrifuged $(1350 \times g, 20 \mathrm{~min})$, the supernantant removed, and the cell pellet resuspended in PBS to a final volume of $250 \mu \mathrm{l}$ for inoculation. Sample preparation and inoculation of mice was performed immediately after semen collection.

Blood samples were collected by coccygeal venipuncture in EDTA, untreated and heparinized tubes for DNA extraction, serological and IFN- $\gamma$ analysis, respectively. Samples were taken after semen collection, once weekly and fortnightly from infected and control bulls, respectively. For parasitaemia studies, DNA was extracted from $300 \mu$ l of EDTA-whole blood using a Genomic-Prep Blood DNA isolation Kit (Amersham Biosciences Ltd.) following the manufacturer's instructions. DNA concentration was determined by spectrophotometric analysis at A260/280 nm, and adjusted to at least $5 \mathrm{ng} / \mu \mathrm{l}$. A negative control $(300 \mu \mathrm{l})$ of sterile distilled water (Sigma, USA) and a positive control $(300 \mu \mathrm{l})$ consisting of DNA extracted from $300 \mu \mathrm{l}$ seronegative whole blood sample spiked with $10^{3} \mathrm{~N}$. caninum NC-1 isolate tachyzoites, were processed as described above to detect possible contamination incurred during the DNA extraction process. Blood samples collected into untreated tubes were clotted, serum removed, aliquoted and stored at $-20{ }^{\circ} \mathrm{C}$ until analysis.

\subsection{PCR procedures}

DNA from whole blood, seminal fluid and the nonsperm cell fraction were analysed separately using nested-PCR on the internal transcribed spacer (ITS1) region of $N$. caninum [8]. Nested-PCR was carried out using four oligonucleotides, as previously described by Buxton et al. [9]. Briefly, DNA amplification was performed in $25 \mu \mathrm{l}$ total volume and after the primary amplification, $5 \mu$ l of PCR product was used as template in the secondary amplification reaction mixture. The secondary amplification product was visualized as a $213 \mathrm{bp}$ band by $1 \%$ agarose gel electrophoresis and ethidium bromide staining [2]. For each amplification, extracted DNA and PCR controls equivalent to $10^{2}$ tachyzoites were used as positive controls. To identify false-positive results, negative control reactions (reactions with no template or reactions with DNA from $N$. caninum-negative semen) were added to each PCR set.

$N$. caninum DNA from nested-PCR positive semen samples was quantified by a real-time PCR test based on the Nc-5 sequence using the double-stranded DNAbinding (dsDNA) dye SYBR Green I. Amplification, data acquisition, and data analysis of reactions for the Neospora Nc5 sequence were carried out in the ABI 7700 Prism Sequence Detector (Applied Biosystems), as described by Collantes-Fernández et al. [10]. N. caninum organism number was quantified by interpolation of the corresponding $\mathrm{Ct}$ values (cycle threshold: the fractional cycle number reflecting a positive PCR result) using a DNA standard curve equivalent to $10^{-1}-10^{4}$ tachyzoites. Sequence Detection System Software v.1.6 (Applied Biosystems) was used to analyze the data, and the number of parasites in semen samples (parasite load) was expressed as parasite number per $\mathrm{ml}$ of semen.

\subsection{Bioassay}

Female, inbred athymic BALB/c nu/nu mice (Charles River, Barcelona, Spain), weighing approximately $25 \mathrm{~g}$ were used for the bioassay. Mice were maintained and handled in an environmentally controlled room with 
12:12 light:dark cycles according to standard practices. A parallel experiment using BALB/c nu/nu mice inoculated with different amounts of bovine semen not contaminated and contaminated with different numbers of $N$. caninum tachyzoites (ranging between 0 and $10^{6}$ ) where carried out. Results obtained showed the toxic effects of inoculating more than $400 \mu \mathrm{l}$ of fresh bovine semen and the threshold level of the bioassay oscillated between $10^{2}$ and $10^{3}$ tachyzoites depending on the mouse. Each individual semen sample $(400 \mu \mathrm{l})$ was inoculated intraperitoneally in one mouse (a total of eight mice each sampling day). Inoculation of mice was performed between 49 and 182 days post-infection (p.i.) of the bulls (a total of 22 sampling days). Afterwards, inoculated mice were examined daily and killed with $\mathrm{CO}_{2}$ gas at 20 weeks post-inoculation. At necropsy, brain, lung and liver were removed aseptically and examined by the nested-PCR procedure described above [2].

\subsection{Assessment of N. caninum-specific antibody responses}

Serum samples were assayed for specific IgG antibodies using a commercial kit (CIVTEST $^{\mathrm{TM}}$ ). Briefly, $50 \mu$ l of each sample (1:100 dilution) was dispensed in $N$. caninum tachyzoite soluble antigencoated plates and incubated for $60 \mathrm{~min}$ at $37{ }^{\circ} \mathrm{C}$. Plates were washed three times and $50 \mu l$ of horseradish peroxidase-IgG conjugate was added to each well. After incubation for $60 \mathrm{~min}$ at $37{ }^{\circ} \mathrm{C}$, plates were washed and $50 \mu \mathrm{l}$ of $2,2^{\prime}$-azino-di-(3-ethylbenzylthiazoline-6-sulfonate) (ABTS) substrate was added. Plates were incubated for $15 \mathrm{~min}$ at room temperature and $50 \mu \mathrm{l}$ of stopping solution $(0.125 \%$ hydrochloric acid) was added to each well. Plates were read at $\mathrm{A} 450 \mathrm{~nm}$. Commercial plates coated with $N$. caninum NC-1 isolate tachyzoite soluble antigen $\left(\right.$ CIVTEST $\left.^{\mathrm{TM}}\right)$ were used to assay serum samples for other immunoglobulin isotypes. Anti- IgG1, IgG2, and IgM conjugates were purchased from Serotec (Oxford, UK). The optimal concentration of each conjugate was determined by a checkerboard titration (IgG1 1:100000, IgG2 1:20000, IgM 1:150000) using positive and negative serum samples. ELISA was performed as above, using tetramethylbenzidine (TMB) substrate (Sigma). The coefficients of variation for ELISAs were lower than $10 \%$. Results for IgG are expressed as Relative Index $\times 100$ (IRPC) values. The IRPC was calculated by the following equation:

$\frac{\mathrm{OD}_{\mathrm{s}}-\mathrm{OD}_{\mathrm{nc}}}{\mathrm{OD}_{\mathrm{pc}}-\mathrm{OD}_{\mathrm{nc}}} \times 100$ where OD is the optical density, $\mathrm{s}$ is sample, $\mathrm{nc}$ is the mean negative control and $\mathrm{pc}$ is the mean positive control. Results were expressed as optical densities (OD) for IgG subclasses and IgM responses, respectively. For statistical analysis, only OD values were used.

Undiluted seminal plasma samples were assayed for specific IgG antibodies using a commercial kit $\left(\right.$ CIVTEST $\left.^{\mathrm{TM}}\right)$. Commercial plates coated with $N$. caninum $\mathrm{NC}-1$ isolate tachyzoite soluble antigen $\left(\right.$ CIVTEST $^{\mathrm{TM}}$ ) were used to assay undiluted seminal plasma samples for IgA antibodies. The optimal concentration of anti-IgA conjugate (Serotec) was determined by a checkerboard titration (1:20000) using samples from strongly seropositive and seronegative chronically infected bulls. ELISA was performed as above using TMB substrate (Sigma). Results are expressed as OD values.

\subsection{Assessment of N. caninum-specific IFN- $\gamma$ responses}

Aliquots of heparinized blood $(900 \mu \mathrm{l})$ from each bull were transferred into each of three wells of 24-well tissue culture plates (Soria Greiner, Spain) and cultured with $100 \mu$ l of phosphate-buffered-saline (PBS) (unstimulated control), concanavalin A (ConA, Sigma) at $10 \mu \mathrm{g} / \mathrm{ml}$ to ensure cellular ability to respond to stimulation and secrete IFN- $\gamma$, and with soluble antigen from the $N$. caninum $\mathrm{NC}-1$ isolate. Soluble antigen extract, used in IFN- $\gamma$ analysis, was prepared as follows: to obtain $N$. caninum soluble proteins, purified tachyzoites $\left(2 \times 10^{9}\right)$ were suspended in $1 \mathrm{ml}$ of $10 \mathrm{mM}$ Tris hydrochloride containing $2 \mathrm{mM}$ of phenylmethylsulfonyl fluoride (Sigma Chemical Co., St. Louis, MO, USA), disrupted by ultrasonic treatment (Branson mod. Sonifier 450, Branson Ultrasonic Co., USA) in an icebath, and centrifuged at $10,000 \times g$ for $20 \mathrm{~min}$ at $4{ }^{\circ} \mathrm{C}$. Protein content was determined using the Micro BCA protein assay method (Pierce, Rockford, USA), and the supernatant aliquoted and cryopreserved at $-80{ }^{\circ} \mathrm{C}$. Optimal antigen concentration $(1 \mu \mathrm{l} / \mathrm{ml})$ and remaining assay parameters were determined previously by checkerboard titration using blood from a strongly seropositive bull (data not shown). Cultures were incubated for $16 \mathrm{~h}$ at $37{ }^{\circ} \mathrm{C}, 5 \% \mathrm{CO}_{2}$. Plates were centrifuged at $500 \times g$ for $10 \mathrm{~min}$, plasma was harvested from each well and frozen at $-20{ }^{\circ} \mathrm{C}$ until testing.

To assess IFN- $\gamma$ production, duplicate plasma samples were tested using a commercial ELISA kit (Bovigam IFN- $\gamma$ kit, CSL, Australia), according to the 
manufacturer's recommendations. Briefly, $100 \mu \mathrm{l}$ of each sample (1:2 dilution) was dispensed in anti-bovine IFN- $\gamma$ antibody-coated plates and incubated for $60 \mathrm{~min}$ at room temperature. Plates were washed six times, incubated for $60 \mathrm{~min}$ at room temperature with $100 \mu \mathrm{l}$ of horseradish peroxidase-anti-bovine IFN- $\gamma$ antibody conjugate, washed again and incubated for $30 \mathrm{~min}$ at room temperature with $100 \mu \mathrm{l}$ of TMB substrate. $50 \mu \mathrm{l} /$ well of stopping solution ( $0.5 \mathrm{M}$ sulphuric acid) was added, and plates were read at A450 nm in a Titertek Multiskan ELISA plate reader. Samples were discarded for which the absorbance of the stimulated well, with ConA or antigen, was less than the absorbance of the unstimulated control plus 0.100 absorbance units.

\subsection{Statistical analysis}

Independent two-sample $t$-tests were performed to compare the antibody and IFN- $\gamma$ responses between experimentally infected and control bulls. The association between the detection of Neospora DNA in semen and/or blood and the serological and IFN- $\gamma$ specific responses in experimentally infected bulls were analysed by the Wilkonson Rank-test. Statistical analyses were performed using SAS Software v.8.2. (SAS Institute Inc.). All statistical analyses were considered significant when $P<0.05$.

\section{Results}

\subsection{Clinical observations}

Experimentally infected bulls showed no apparent clinical signs for the duration of the experiment and did not produce a significant rise or fall in temperature when compared with controls (data not shown).

\subsection{Parasitaemia}

Five of the bulls showed parasitaemia between 14 and 18 days p.i., one bull at 14 and 46 days p.i. and the other two bulls at 49 and 72 days p.i., respectively (Table 1).

\subsection{Detection of N. caninum DNA in semen and bioassay}

The presence of $N$. caninum DNA in semen samples is depicted in Table 1 . The eight experimentally infected bulls showed $N$. caninum DNA in their semen samples at some time during the course of the study. The $N$. caninum DNA in semen samples was detected after the

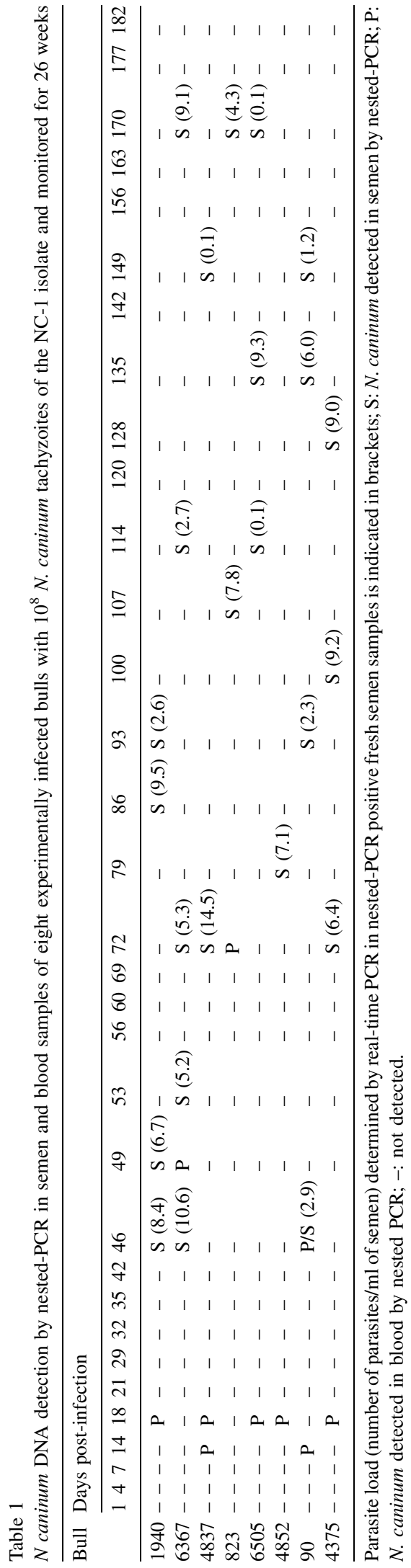


presence of parasitaemia except in one bull. In all positive semen samples, specific DNA was consistently found in the cellular fraction and not in seminal plasma. Three bulls began to show $N$. caninum DNA in their semen at 46 days p.i. and the other five bulls between 72 and 149 days p.i. The presence of $N$. caninum DNA in semen was intermittent and associated with the chronic stage of infection. The parasite load, as determined by real-time PCR from nested-PCR positive semen samples, varied from 0.1 to 14.5 parasites per $\mathrm{ml}$ of semen (mean 6.0 \pm 3.0 ) (Table 1). Mean individual parasite load varied from $3.1( \pm 2.1)$ to $8.2( \pm 1.6)$. No
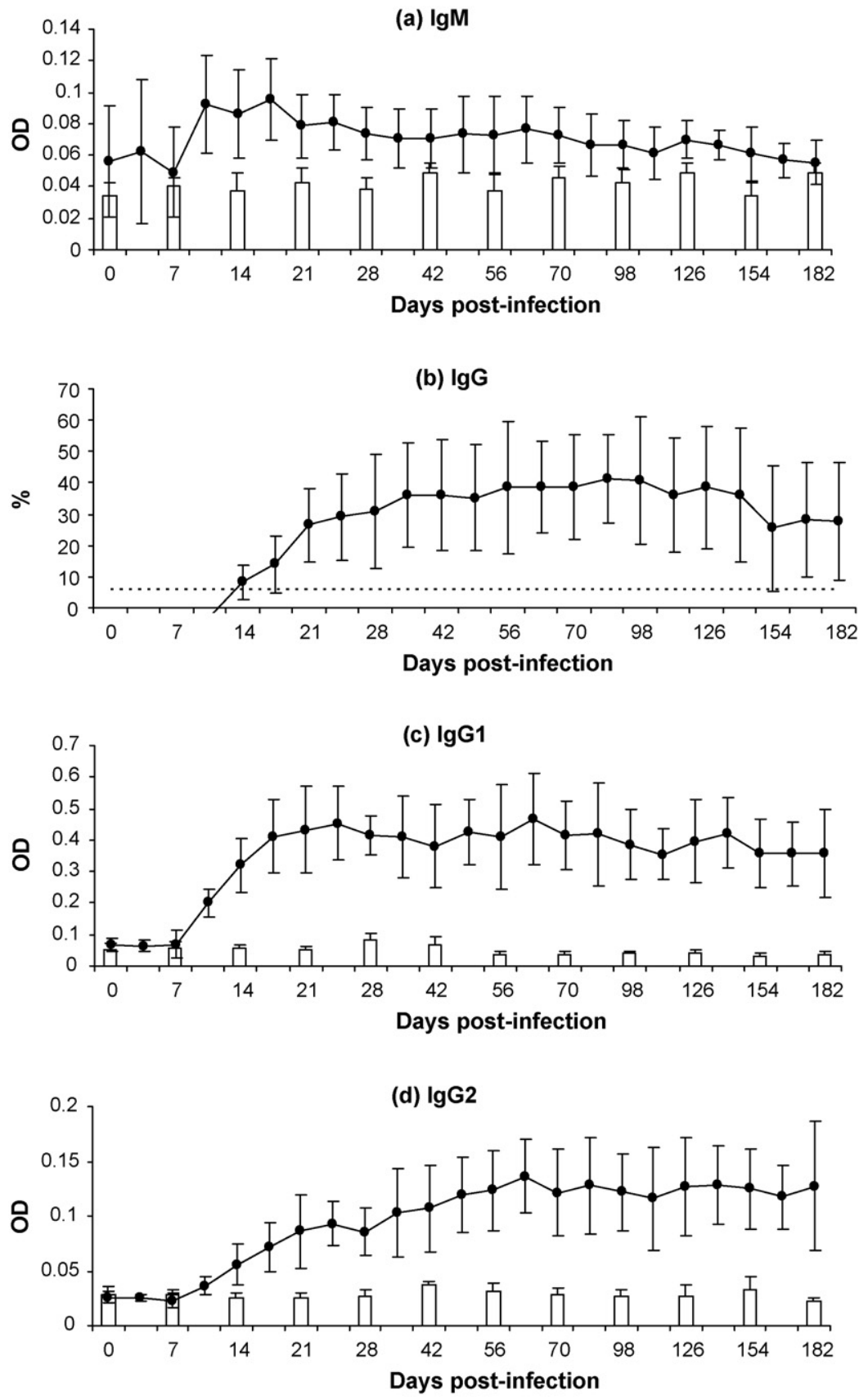

Fig. 1. Serum specific antibody responses in bulls experimentally infected with $10^{8}$ tachyzoites of $N$. caninum (NC-1 isolate) and monitored for 26 weeks: (a) IgM; (b) IgG; (c) IgG1; and (d) IgG2. For IgM and IgG subclasses the graphs show the mean OD \pm S.D. of eight infected (solid doted black line) and eight control (vertical white bars) bulls. IgG results are expressed as relative index $\times 100$ values and the cut-off value is signed as a broken line. 


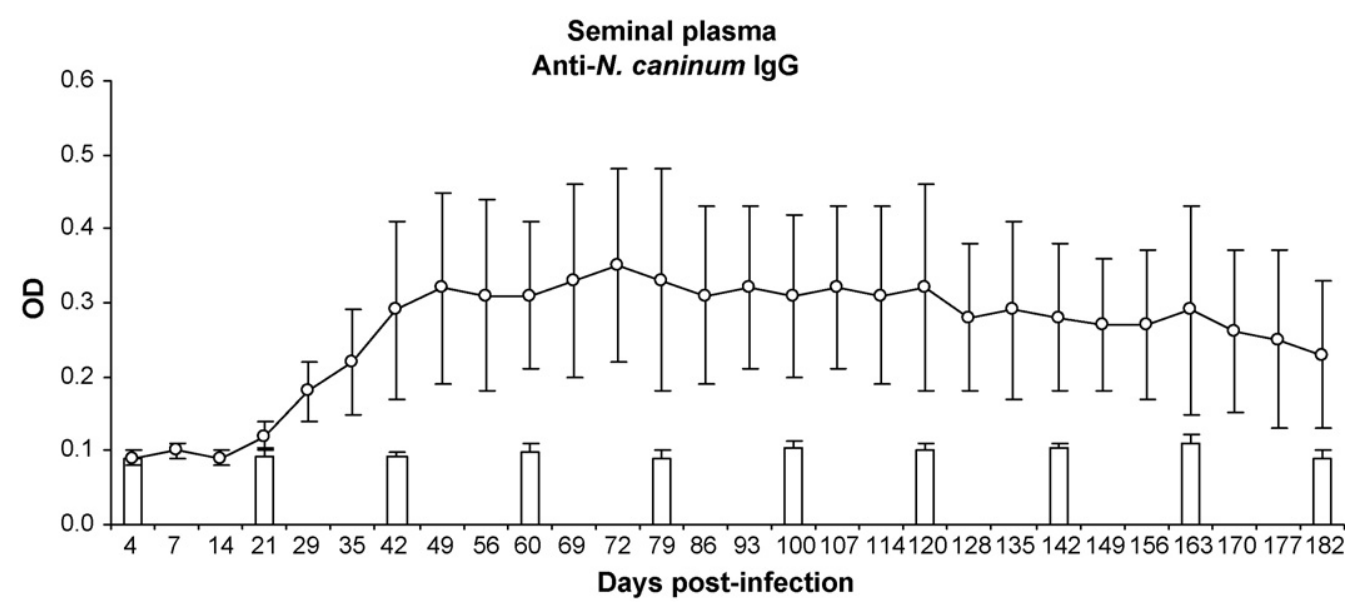

Fig. 2. Anti- $N$. caninum $\mathrm{IgG}$ responses in seminal plasma of bulls experimentally infected with $10^{8}$ tachyzoites of NC- 1 isolate and monitored for 26 weeks. The graph shows the mean $\mathrm{OD} \pm$ S.D. of eight infected (solid doted white line) and eight control (vertical white bars) bulls.

specific DNA was detected in any of the semen samples from control bulls.

A total of 176 athymic mice were inoculated with semen samples. Twenty-one mice were inoculated with a PCR-positive semen sample and the number of parasites in each inoculum oscillated between 0.04 and 5.8 tachyzoites. No $N$. caninum DNA was detected by nested-PCR in the brain, lung or liver of BALB/c nu/nu mice inoculated with semen samples.

\subsection{N. caninum-specific antibody responses}

Serum specific antibody responses to $N$. caninum in experimentally infected bulls are shown in Fig. 1. A significantly increased $(P<0.05)$ mean serum specific IgM antibody response to $N$. caninum in experimentally infected bulls compared to controls was detected between 10 and 28 days p.i. (Fig. 1a). Subsequently, IgM levels were slightly higher than those observed in control bulls until 154 days p.i., although not significantly. Anti-N. caninum IgG was detected 14 days p.i. and was significantly different $(P<0.05)$ from controls at 21 days p.i. (Fig. 1b). Serum IgG antibody responses of individual animals were similar in kinetics but slightly different in magnitude. In one bull (no. 1940), the IgG level fell below cut-off value at days 154 and 182 p.i. Specific IgG1 and IgG2 serum levels were first detected 7 (Fig. 1c) and 10 (Fig. 1d) days p.i., respectively. Anti-N. caninum $\mathrm{IgG} 1$ and $\mathrm{IgG} 2$ levels were significantly different $(P<0.05)$ in experimentally-infected bulls by days 10 and 14 , respectively. The mean IgG1/IgG2 ratio progressively decreased in experimentally infected bulls compared to controls between 84 and 182 days p.i., but not significantly (data not shown). The eight control bulls remained seronegative throughout the study. No significant association was found between the presence and parasite load of $N$. caninum DNA in semen and the magnitude of specific IgG, IgG1, IgG2 or IgM responses.

Anti- $N$. caninum $\operatorname{IgG}$ was detected 21 days p.i. in seminal plasma and was significantly different $(P<0.05)$ from controls at 29 days p.i. (Fig. 2). No differences were detected in $\operatorname{IgA}$ antibody levels in seminal plasma between infected and control bulls (data not shown).

\subsection{N. caninum-specific IFN- $\gamma$ responses}

Serum specific IFN- $\gamma$ responses in experimentally infected bulls were significantly higher $(P<0.05)$ than controls as soon as 3 days p.i. (Fig. 3). Subsequently

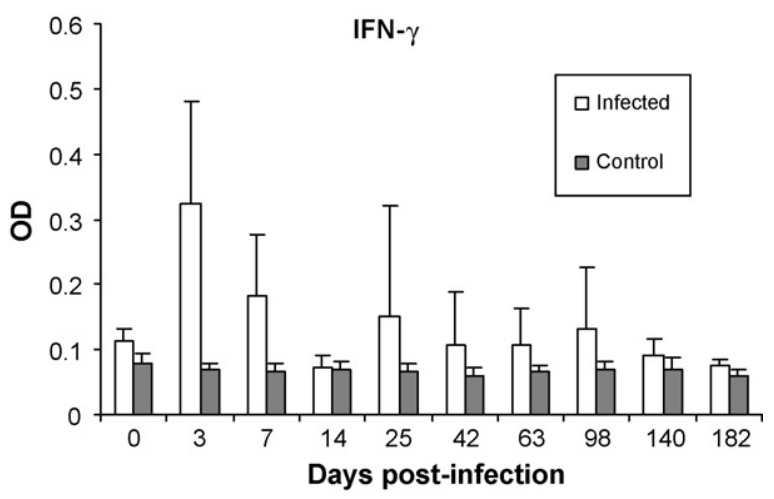

Fig. 3. Specific IFN- $\gamma$ response to $N$. caninum in bulls experimentally infected with $10^{8}$ tachyzoites of $N$. caninum (NC-1 isolate) and monitored for 26 weeks. Vertical white and grey bars show the mean $\mathrm{OD} \pm$ S.D. of eight infected and control bulls, respectively. 
however, IFN- $\gamma$ levels showed a slight decrease in all bulls except one (no. 6505), who showed significantly higher $(P<0.05)$ levels than control bulls between 25 and 105 days p.i. (not shown). Mean IFN- $\gamma$ levels in other experimentally infected bulls were higher than control bulls until 140 days p.i., but not significantly. No significant associations were observed between the presence and magnitude of $N$. caninum DNA in semen and IFN- $\gamma$ production levels. In addition, we found no significant association among IgG2 antibody levels, IgG1/IgG2 ratio, and IFN- $\gamma$ levels in experimentally infected bulls.

\section{Discussion}

The present study of eight experimentally infected bulls was designed to investigate the presence of $N$. caninum in semen and blood and correlate their occurrence and timing with specific antibody and IFN- $\gamma$ responses. Our results demonstrated that after intravenous inoculation with $N$. caninum tachyzoites, all bulls mounted early specific humoral and cellmediated immune responses, and $N$. caninum DNA was detected intermittently in the semen of all animals following parasitaemia in association with the chronic stage of the infection.

The intermittent pattern of $N$. caninum DNA presence in the semen of experimentally infected bulls was similar to that observed in naturally infected animals [4]. However, it is noteworthy that all experimentally infected bulls showed specific DNA in their semen samples at some time during the course of the 26 week-study, but we were only able to detect PCR-positive semen samples in six of eight naturally infected bulls monitored for 22 weeks [4]. Low parasite numbers in semen samples and/or intermittent shedding of the protozoa into semen could explain the intermittent detection of $N$. caninum in bull semen. Despite the low parasite load observed in PCR-positive semen samples (the maximum number estimated was barely 15 parasites $/ \mathrm{ml}$ of semen), we do not believe that low numbers of parasite template in semen to impede detection by nested-PCR. The nested-PCR used to detect $N$. caninum DNA in semen samples is highly sensitive, amplifying DNA products corresponding to one tachyzoite in $250 \mu \mathrm{l}$ of artificially-contaminated semen [2-4]. The non-uniform $N$. caninum distribution and the limited amount of parasite DNA present in fluids and tissues have been reported in naturally or experimentally infected adult cattle [11,12]. Moreover, infected seropositive cattle testing negative for specific DNA in the semen, as assessed by PCR, have been reported for other infectious agents such as Brucella melitensis [13] or bovine herpesvirus type 1 [14].

Tachyzoites, the invasive stage of $N$. caninum found in many cell types and tissues, are most likely the parasite form excreted into semen because cysts containing bradyzoites have been reported in the central and peripheral nervous system of cattle (especially in the brain) and skeletal muscle [15].

As we have previously described in fresh and frozen semen samples from naturally infected bulls $[3,4]$, the presence of $N$. caninum DNA in the semen of experimentally infected animals seems to be associated with the cellular fraction of semen. It appears that certain cell types that are present in the cellular fraction of semen could harbour $N$. caninum tachyzoites because virtually no specific DNA was present in seminal fluid. It is likely that immune cells, such as mononuclear phagocytic cells, are responsible for protozoa transport in blood, semen and other organic fluids, as circulating antibodies and complement could easily kill extracellular tachyzoites during reactivation [16]. Trafficking of leukocytes to disseminate intracellular parasites via a Trojan horse-type mechanism has been postulated for other apicomplexan parasites, such as Toxoplasma gondii [17]. At present, N. caninum DNA has been found in the white cell fraction of blood in naturally [18] and experimentally [19] infected cows. In addition, $N$. caninum antiserum has been found to bind to phagocytes [20] and the related coccidian, T. gondii, has been demonstrated to be resistant to lysis after internalization by macrophages [21].

Our inability, in this study, to isolate the parasite from PCR positive semen samples is noteworthy. Thus, we cannot conclude that live $N$. caninum was present in positive semen samples and our lack of success could be explained in one of two ways. First, the toxic effects of bovine semen meant that it was not possible to inoculate more than $400 \mu \mathrm{l}$ of fresh semen into an athymic BALB/c nu/nu mouse, and second, the low parasite load found in semen. Positive semen samples were inoculated immediately after semen extraction so that parasite viability would not be compromised. Based on parasite load determined in positive semen samples, the total number of parasites in $400 \mu \mathrm{l}$ of fresh bovine semen was approximately between 0.04 and 5.8 tachyzoites. In recent studies it has been shown that it is necessary for bovine semen to contain between $10^{2}$ and $10^{3}$ tachyzoites in order to induce an infection in athymic BALB/c nu/nu mice (our unpublished data). However, the susceptibility of nude mice to N. caninum is well documented [22] and the athymic mouse model has been used satisfactorily 
for Neospora isolation from bovine brain in our laboratory (unpublished data).

The current study of eight experimentally infected bulls shows a maximum number of 15 tachyzoites per $\mathrm{ml}$ of semen, equivalent to an ejaculate containing approximately 150 parasites. Recently, we reported a threshold level of between 5000 and 50,000 tachyzoites for venereal route [7]. This number seems very different in comparison to the parasite load described in naturally and experimentally infected bulls. However, the repeated services of ejaculates containing 100-150 tachyzoites, which is common in beef cattle breeds under extensive management [23], could possibly attain the minimum number of tachyzoites required to induce infection. In addition, infection could be facilitated by parasites enclosed in host cells, such as mononuclear phagocytic cells. Under these conditions, tachyzoites could be more resistant to passage through the genital tract than free tachyzoites, thereby retaining infectivity when reaching the uterine mucosa. As we previously mentioned, our observations that most $N$. caninum DNA is found in the cellular fraction and virtually no specific DNA is present in seminal fluid also supports this hypothesis [3,4].

The specific IgG antibody profile in experimentally infected bulls was similar to that observed in other nonpregnant cattle [24-26]. In one bull, antibody levels were sometimes close to threshold levels, and even fell to very low values that would normally be considered seronegative. Previous studies with naturally infected bulls showed predominantly low specific antibody titres in serum near threshold levels of the techniques employed [23,27]. Low serum antibody levels have been associated with chronic infection, but antibody fluctuations have been reported in adult cattle $[26,28]$ as well as young calves experimentally infected with $N$. caninum [24], particularly in animals infected with a low dose.

It is significant that specific $\operatorname{IgG}$ antibodies to $N$. caninum were detected in the seminal plasma of all experimentally infected bulls. Seminal plasma IgG levels followed a similar pattern to serum $\operatorname{IgG}$ and it suggests that $\operatorname{IgG}$ in seminal plasma could derive directly from the bloodstream. Lack of a seminal plasma specific IgA response to $N$. caninum also supports this hypothesis. This study is the first to report the presence of $N$. caninum antibodies in seminal plasma. Previous studies carried out in Argentina using three bulls experimentally infected with $3 \times 10^{7} \mathrm{~N}$. caninum tachyzoites failed to detect specific antibodies in seminal plasma samples using an immunofluorescent antibody test (Campero et al., personal communica- tion). Discrepancies between results could be explained by the higher sensitivity and specificity of the ELISA technique used [22]. Our results suggest that detection of specific antibodies to $N$. caninum in seminal plasma by ELISA, which is especially useful in bulls from AI centres, could be an alternative to serology for the diagnosis of bovine neosporosis. However, further experiments are required to determine its usefulness in naturally infected animals. A possible toxic effect of specific antibodies during parasite shedding in semen was not investigated. However, as we postulated previously, the presence of $N$. caninum DNA associated with the cellular fraction of semen strongly suggests an association between N. caninum and phagocytic cells, which could act as carriers protecting the protozoa.

$N$. caninum IgG subclasses and IFN- $\gamma$ levels were evaluated in this study to asses the type of immune response induced in experimentally infected bulls. Monitored bulls showed a IgG1 response and significant IFN- $\gamma$ levels were detected during the entire experimental period. Our results are consistent with previous studies showing a predominant IgG1 response in calves orally infected with $N$. caninum oocysts [25], heifers inoculated with $N$. caninum tachyzoites by seminal infection [6], and pregnant cows intravenously-intramuscularly inoculated with $N$. caninum tachyzoites [29]. The lack of correlation between IgG titres and IFN- $\gamma$ levels has been reported in experimentally infected cattle $[4,29,30]$, suggesting that factors other than IFN- $\gamma$ regulate IgG antibody production in cattle.

This is the first study to report the presence of $N$. caninum DNA in the semen of experimentally infected bulls. Our observations indicate intermittent $N$. caninum shedding in semen associated with chronic stage of infection. In addition, mean parasite load in semen was twice the quantity reported in bulls naturally infected by $N$. caninum, but inadequate for isolation using an athymic mouse model. The current work and previous studies $[2,4,6,7]$ have focused on the feasibility of horizontal transmission via contaminated semen to be responsible for bovine neosporosis. Present evidence suggests the occurrence of this to be very unlikely. However, at present our studies are focused on assessing the possible role of venereal transmission during the spread of bovine neosporosis under natural conditions.

\section{Acknowledgements}

We are grateful to ASEAVA (Asociación de Criadores de Ganado Vacuno Selecto de la Raza Asturiana de los Valles) for providing experimental animals, and specially to José Antonio Cachero and José 
Luis Antón (SERIDA) and Vanesa Navarro (UCM) for technical assistance. Funding for this work was provided by a research grant from the Spanish government (Pr95-0780.OP). Ignacio Ferre was financed by the Ramón y Cajal Spanish Scientific Programme. This work was also part of the EU research collaboration COST-854. This experiment complied with the current laws of animal protection in Spain.

\section{References}

[1] Dubey JP. Neosporosis in cattle. J Parasitol 2003;89:S42-56.

[2] Ortega-Mora LM, Ferre I, del-Pozo I, Caetano-da-Silva A, Collantes-Fernández E, Regidor-Cerrillo J, Ugarte-Garagalza C, Aduriz G. Detection of Neospora caninum in semen of bulls. Vet Parasitol 2003;117:301-8.

[3] Caetano-da-Silva A, Ferre I, Collantes-Fernández E, Navarro V, Aduriz G, Ugarte-Garagalza C, Ortega-Mora LM. Occasional detection of Neospora caninum DNA in frozen extended semen from naturally infected bulls. Theriogenology 2004;62: 1329-36.

[4] Ferre I, Aduriz G, del-Pozo I, Regidor-Cerrillo J, Atxaerandio R, Collantes-Fernández E, Hurtado A, Ugarte-Garagalza C, OrtegaMora LM. Detection of Neospora caninum in the semen and blood of naturally infected bulls. Theriogenology 2005;63: 1504-18.

[5] Staubli D, Iten C, Kneubuhler J, Sager H, Muller N, Gottstein B. Search for Neospora caninum DNA in bull semen using PCR (in German). Schweiz Arch Tierheilkd 2006;148:483-9.

[6] Serrano E, Ferre I, Osoro K, Aduriz G, Mateos-Sanz A, Martínez A, Atxaerandio R, Hidalgo CO, Ortega-Mora LM. Intrauterine Neospora caninum inoculation of heifers. Vet Parasitol 2006;135:197-203.

[7] Serrano-Martínez E, Ferre I, Osoro K, Aduriz G, Mota RA, Martínez A, del-Pozo I, Hidalgo CO, Ortega-Mora LM. Intrauterine Neospora caninum inoculation of heifers and cows using contaminated semen with different numbers of tachyzoites. Theriogenology 2007;67:729-37.

[8] Payne S, Ellis J. Detection of Neospora caninum DNA by the polymerase chain reaction. Int J Parasitol 1996;26:347-51.

[9] Buxton D, Maley SW, Wright S, Thomson KM, Rae AG, Innes EA. The pathogenesis of experimental neosporosis in pregnant sheep. J Comp Pathol 1998;118:267-79.

[10] Collantes-Fernández E, Zaballos A, Álvarez-García G, OrtegaMora LM. Quantitative detection of Neospora caninum in bovine aborted fetuses and experimentally infected mice by real-time PCR. J Clin Microbiol 2002;40:1194-8.

[11] Trees AJ, McAllister MM, Guy CS, McGarry JW, Smith RF, Williams DJL. Neospora caninum: oocyst challenge of pregnant cows. Vet Parasitol 2002;109:147-54.

[12] Williams DJL, Guy CS, McGarry JW, Guy F, Tasker L, Smith RF, MacEachern K, Cripps PJ, Kelly DF, Trees AJ. Neospora caninum-associated abortion in cattle: the time of experimentally-induced parasitaemia during gestation determines foetal survival. Parasitology 2000;121:347-58.

[13] Amin AS, Hamdy MER, Ibrahim AK. Detection of Brucella melitensis in semen using the polymerase chain reaction assay. Vet Microbiol 2001;83:37-44
[14] Rocha MA, Barbosa EF, Guimaraes SEF, Dias-Neto E, Gouveia AMG. A high sensitivity-nested PCR assay for BHV-1 detection in semen of naturally infected bulls. Vet Microbiol 1998;63:1-11.

[15] Dubey JP. Review of Neospora caninum and neosporosis in animals. Korean J Parasitol 2003;41:1-16.

[16] Hemphill A. The host-parasite relationship in neosporosis. Adv Parasitol 1999;43:47-104.

[17] Barragan A, Sibley LD. Migration of Toxoplasma gondii across biological barriers. Trends Microbiol 2003;11:426-30.

[18] Okeoma CM, Williamson NB, Pomroy WE, Stowell KM, Gillespie L. The use of PCR to detect Neospora caninum DNA in the blood of naturally infected cows. Vet Parasitol 2004;122: 307-15.

[19] Macaldowie C, Maley SW, Wright S, Bartley P, EstebanRedondo I, Buxton D, Innes EA. Placental pathology associated with fetal death in cattle inoculated with Neospora caninum by two different routes in early pregnancy. J Com Pathol 2004;131: 142-56.

[20] Boger LA, Hattel AL. Additional evaluation of undiagnosed bovine abortion cases may reveal fetal neosporosis. Vet Parasitol 2003;113:1-6.

[21] McLeod R, Mack D, Brown C. T. gondii: new advances in cellular and molecular biology. Exp Parasitol 1991;72:109-21.

[22] Dubey JP, Schares G. Diagnosis of bovine neosporosis. Vet Parasitol 2006;140:1-34

[23] Moore DP, Draghi MG, Campero CM, Cetrá B, Odeón AC, Alcaraz E, Späth EAJ. Serological evidence of Neospora caninum infections in beef bulls in six counties of the Corrientes province, Argentina. Vet Parasitol 2003;114:247-52.

[24] Maley SW, Buxton D, Thomson KM, Schriefer ES, Innes EA Serological analysis of calves experimentally infected with Neospora caninum: a 1-year study. Vet Parasitol 2001;96:1-9.

[25] De-Marez T, Liddell S, Dubey JP, Jenkins MC, Gasbarre L. Oral infection of calves with Neospora caninum oocysts from dogs: humoral and cellular immune responses. Int $\mathbf{J}$ Parasitol 1999;29:1647-57.

[26] Conrad PA, Sverlow K, Anderson M, Rowe J, BonDurant R, Tuter G, Breitmeyer R, Palmer C, Thurmond M, Ardans A, Dubey JP, Duhamel G, Barr B. Detection of serum antibody responses in cattle with natural or experimental Neospora caninum infection. J Vet Diagn Invest 1993;5:572-8.

[27] Caetano-da-Silva A, Ferre I, Aduriz G, Alvarez-García G, delPozo I, Atxaerandio R, Regidor-Cerrillo J, Ugarte-Garagalza C, Ortega-Mora LM. Neospora caninum infection in breeder bulls: seroprevalence and comparison of serological methods used for diagnosis. Vet Parasitol 2004;124:19-24.

[28] Pereira-Bueno J, Quintanilla-Gozalo A, Seijas-Carballedo A, Costas E, Ortega-Mora LM. Observational studies in Neospora caninum infected dairy cattle: pattern of transmission and agerelated antibody fluctuations. Int J Parasitol 2000;30:906-9.

[29] Andrianarivo AG, Barr BC, Anderson ML, Rowe JD, Packham $\mathrm{AE}$, Sverlow KW, Conrad PA. Immune responses in pregnant cattle and bovine fetuses following experimental infection with Neospora caninum. Parasitol Res 2001;87:817-25.

[30] Andrianarivo AG, Rowe JD, Barr BC, Anderson ML, Packham AE, Sverlow KW, Choromanski L, Loui C, Grace A, Conrad PA. A POLYGEN ${ }^{\mathrm{TM}}$-adjuvanted killed Neospora caninum tachyzoite preparation failed to prevent foetal infection in pregnant cattle following i.v./i.m. experimental tachyzoite challenge. Int J Parasitol 2000;30:985-90. 